\title{
Review
}

\section{Animal brucellosis in Egypt}

\author{
Gamal Wareth ${ }^{1,2,3}$, Ahmed Hikal ${ }^{4}$, Mohamed Refai ${ }^{5}$, Falk Melzer ${ }^{1}$, Uwe Roesler $^{2}$, Heinrich Neubauer ${ }^{1}$ \\ ${ }^{1}$ Friedrich-Loeffler-Institut, Federal Research Institute for Animal Health, Institute of Bacterial Infections and \\ Zoonoses, Jena, Germany \\ ${ }^{2}$ Institute of Animal Hygiene and Environmental Health, Free University of Berlin, Berlin, Germany \\ ${ }^{3}$ Department of Pathology, Faculty of Veterinary Medicine, Benha University, Qalyobia, Egypt \\ ${ }^{4}$ Department of Microbiology, Faculty of Veterinary Medicine, Benha University. Qalyobia, Egypt \\ ${ }^{5}$ Department of Microbiology, Faculty of Veterinary Medicine, Cairo University. Giza, Egypt
}

\begin{abstract}
Brucellosis is a highly contagious zoonosis that affects the public health and economic performance of endemic as well as non-endemic countries. In developing nations, brucellosis is often a very common but neglected disease. The purpose of this review is to provide insight about brucellosis in animal populations in Egypt and help to understand the situation from 1986 to 2013 . A total of 67 national and international scientific publications on serological investigations, isolation, and biotyping studies from 1986 to 2013 were reviewed to verify the current status of brucellosis in animal populations in Egypt. Serological investigations within the national surveillance program give indirect proof for the presence of brucellosis in cattle, buffaloes, sheep, goats, and camels in Egypt. Serologic testing for brucellosis is a wellestablished procedure in Egypt, but most of the corresponding studies do not follow the scientific standards. B. melitensis biovar (bv) 3 , B. abortus bv 1 , and $B$. suis bv 1 have been isolated from farm animals and Nile catfish. Brucellosis is prevalent nationwide in many farm animal species. There is an obvious discrepancy between official seroprevalence data and data from scientific publications. The need for a nationwide survey to genotype circulating Brucellae is obvious. The epidemiologic situation of brucellosis in Egypt is unresolved and needs clarification.
\end{abstract}

Key words: brucellosis; biotyping; Egypt; isolation; seroprevalence.

J Infect Dev Ctries 2014; 8(11):1365-1373. doi:10.3855/jidc.4872

(Received 18 February 2014 - Accepted 04 August 2014)

Copyright (C) 2014 Wareth et al. This is an open-access article distributed under the Creative Commons Attribution License, which permits unrestricted use, distribution, and reproduction in any medium, provided the original work is properly cited.

\section{Introduction}

Brucellosis is caused by bacteria of the genus Brucella. Brucellae are small Gram-negative, nonmotile, non-spore forming, aerobic, facultative intracellular coccobacilli capable of invading epithelial cells, placental trophoblasts, dendritic cells, and macrophages [1]. The genus includes 10 nomo-species based on their different host specificity [2]. The six classical species are B. melitensis biovar (bv) 1-3, mainly isolated from sheep and goats; $B$. abortus bv 1-6 and 9, primarily isolated from cattle and buffaloes; $B$. suis bv 1-3, mainly isolated from pigs, bv 4 from reindeer and bv 5 isolated from small ruminants; $B$. canis isolated from dogs; $B$. ovis isolated from sheep; and $B$. neotomae isolated from desert wood rats [3]. Recently, four new species have been described. Two are of marine origin ( $B$. pinnipedialis from seals, and $B$. ceti from dolphins and whales). $B$. microti was isolated from the common vole Microtus arvalis [4]. Finally, B. inopinata was isolated from a breast implant wound of a female patient [5].

Brucellosis, caused by $B$. melitensis, B. abortus, $B$. suis (except bv 2) and in rare cases B. canis, is a highly contagious and zoonotic disease affecting livestock and humans worldwide. In animals, brucellosis causes tremendous economic losses [6]. The disease provokes abortion, stillbirth, mastitis, metritis, and placental retention in females and orchitis and arthritis in males. Infertility may be seen in both sexes. The true incidence of human brucellosis is not easy to estimate globally, but an estimated 500,000 persons are newly infected every year [7]. The World Health Organization considers brucellosis a neglected zoonosis and classifies Brucellae as risk group III agents because they can be easily transmitted via aerosols [8]. Airborne transmission of B. melitensis infection has been previously described [9], and Brucellae have previously been used as biological agents in weapons of mass destruction [7]. 


\section{Brucella in Egypt}

It is likely that brucellosis has been an endemic disease in Egypt for thousands of years. For example, there is evidence in $5.2 \%$ of bone remnants from ancient Egyptians (750 BCE) of sacroiliitis in pelvic bones, and evidence of spondylitis and osteoarticular lesions have also been found, both common complications of brucellosis [10]. In 1939, brucellosis was reported in a scientific report from Egypt for the first time [11]. Since then, the disease has been detected at high levels among ruminants, particularly in large intensive breeding farms (Refai, personal communication, 20.07.2013). Consequently, a control program including serological surveys and voluntary vaccination of ruminants was established in the early 1980s [12].

Indirect techniques regularly used in diagnosis of Brucella are field tests such as the milk ring test (MRT), serological tests such as the standard agglutination test (SAT) and buffered agglutination test, which are confirmed by the complement fixation test (CFT) and enzyme-linked immunosorbant assay (ELISA) [13]. Serological diagnosis of Brucellae currently relies mainly on the detection of antiBrucella lipopolysaccharide (LPS) antibodies. In $B$. melitensis, B. abortus, and B. suis, the LPS is smooth (containing an O-polysaccharide); B. canis isolates lack the O-polysaccharide and are considered rough. However, these tests cannot differentiate antibodies originating from vaccine or wild-type strains. The tests are also prone to false-negative and false-positive reactions, the latter caused by cross-reactions with LPS of other Gram-negative bacteria [14].

Isolation of Brucellae is still the gold standard for diagnosis; however, this method often fails due to the delays in symptoms, resulting in incorrect sample types and low bacterial loads in specimens such as blood, milk, or tissue. Biotyping of isolates involves evaluation of a combination of growth characteristics (colonial morphology, oxidase, urease, $\mathrm{CO}_{2}$ requirement, $\mathrm{H}_{2} \mathrm{~S}$ production, growth in presence of the dyes fuchsin and thionin), lysis by bacteriophage (Tiblisi and $\mathrm{R} / \mathrm{C}$ ), and agglutination with monospecific $\mathrm{A}, \mathrm{M}$, and $\mathrm{R}$ anti-sera [2,15]. Although various polymerase chain reaction (PCR) assays have been created to diagnose Brucellae at the species level (e.g., the Abortus, Melitensis, Ovis, Suis AMOS PCR), these assays are most useful when applied to DNA extracted from a positive culture.

A comprehensive, evidence-based assessment of current literature and of officially available data on animal brucellosis is missing for Egypt. The aim of this review is to provide insight regarding brucellosis in Egypt over the last 27 years and to assist observers interested in Brucellosis to more fully understand the situation in Egypt.

\section{Literature search and data collection}

National and international publications on serological investigations and on typing studies of brucellosis from 1986 to 2013 were obtained through PubMed, Science Direct, Google, and from Egyptian university libraries such as The Egyptian National Agricultural Library (ENAL) and the Federation of Egyptian University Libraries. The following search terms were used: brucellosis in Egypt, Brucella infection in Egypt, Brucella in animals in Egypt, and animal brucellosis in Egypt. Theses dealing with brucellosis available from Egyptian universities were included in this study (1986-2013). The libraries were personally visited or contacted via e-mail. Reports on brucellosis from the General Organization of Veterinary Services in Egypt (GOVS) from January 2006 through December 2011 were investigated. Studies dealing with human infection were excluded.

A full text analysis of each publication was done by at least two reviewers. Publications describing serological investigations were included even if statistical analyses were not sound to avoid loss of data. Publications on cultivation, bio- and genotyping or PCR analyses were included only if state-of-the-art techniques could be verified by the respective material, and if the methods sections and results were clear. To clarify ambiguities, the authors were first contacted by e-mail or phone. If the authors could resolve those ambiguities, the publications were accepted for further assessment. The following data were extracted from the manuscripts, reports, or theses: seroprevalence for brucellosis in host species populations and regional distribution, prevalence of Brucellae in animals or food proofed, and identification of isolates.

\section{Data acquisition}

A total of 25 scientific papers on seroprevalence $[6,12,16-38]$ and 18 on isolation of Brucellae $[11,16,17,20,22,25,26,29,31,33-35,38-43] \quad$ were identified by online search. Local scientific papers and 10 theses were obtained from Egyptian universities; 28 of them dealt with seroprevalence [44-71] and 16 dealt with isolation of Brucellae [44,45,48-51,53$55,58,68,72-77]$. The official data collection of the General Organization of Veterinary Services (GVOS) was evaluated for the years 1999 to 2011. Two 
publications on serology $[31,38]$ and nine on isolation of Brucellae [17,20,35,38,39,41,48,55,58] were finally excluded from evaluation because ambiguities were identified within the materials and methods sections and the authors could not be contacted to resolve these ambiguities.

\section{Serological investigations}

Information on serological investigations was provided by the General Organization of Veterinary Service (GOVS), Cairo, Egypt, as official reports from 1999 to 2011. Screening with the Rose Bengal plate agglutination test (RBPT) and Rivanol test followed by confirmatory CFT in screening test-positive animals is the approved technical procedure of the official control program. This procedure is in accordance with the procedures proposed in the World Organisation for Animal Health (OIE) manual of standard diagnostic tests and vaccines. Serological investigations within the national surveillance program give indirect proof for the presence of brucellosis in cattle, buffaloes, sheep, and goats in 22 of 27 governorates. Ismailia, Red Sea, North Sinai, South Sinai, and Matroh did not report seropositive animals. The total number of animals steadily increased during the reporting time (Figure 1). Sheep and goats had a higher seroprevalence than did cattle and buffaloes (Table 1). Peaks were seen in 2002/2003 and 2008/2009/2010 (Figure 2). The number of animals tested was always very low when compared to the total number of animal stocks in Egypt according to the Food and Agriculture Organization (FAO) registers (Table 1). Sampling plans were not made available. It cannot be excluded that sampling is biased; therefore, only tendencies should be read. Based on this data, it can be concluded that brucellosis

Figure 1. Total number of animals in Egypt, 1999-2011 (FAO, 2013).

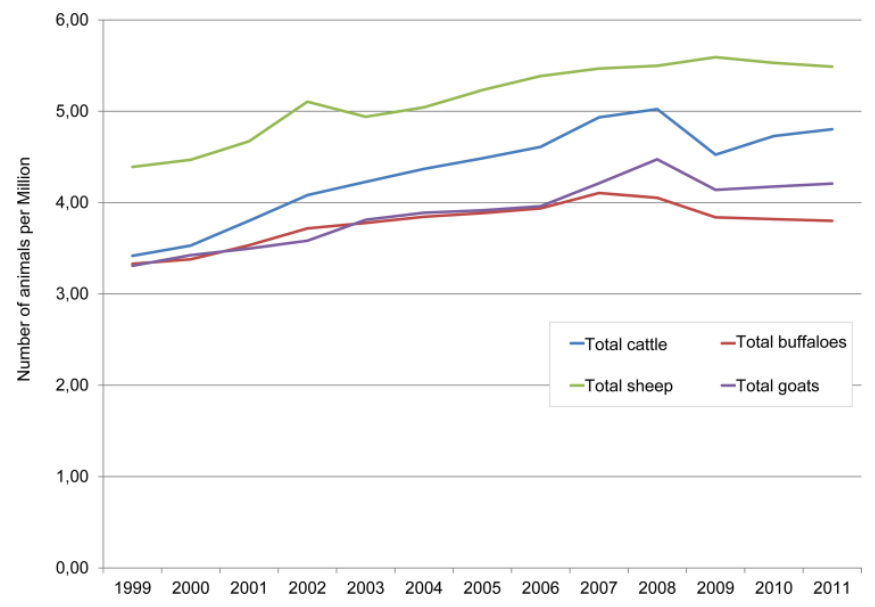

is present in all governorates in cattle, buffaloes, goats, and sheep. The lowest total percentage of seropositive animals was recorded in 2011 with $0.33 \%$. In 2011, the riots and civil commotions of the Arab Spring lead to a depletion of state resources, resulting in low numbers of animals tested, a decrease of the reimbursement funds for owners, and increased animal movement within villages and governorates.

A total of 53 scientific publications and theses on serological investigations were selected for review. Serological studies were made in Qalyobia, Menufiya, Gharbia, Behira, Alexandria, Kafrelsheikh, Dakahlia, Sharkia, Giza, Fayoum, Beni-Suef, El-Minia, Assuit, New Valley, Sohag, Qina, Luxor, and Aswan in bovines, small ruminants, camels, and Nile catfish, rendering positive results. Assuit, Menufiya, Kafrelsheikh, Giza, and Behira have been studied very well; they have been included in more than five investigations (Supplementary Table 1). Most studies were made in response to clinical events such as notice of late abortion, elevated levels of insemination, and mastitis. As such, these studies do not comply with the standards for epidemiological investigations concerning study design or biostatistics. However, they show that in infected animal herds, the prevalence rate may be high independent of the animal species $(1 \%-100 \%)$. In cross-sectional studies, approximately $15 \%$ of households in a study area kept animals and within a herd, up to $15 \%$ (cattle and buffaloes) or even more (sheep and goats) animals could be expected to be seropositive $[6,19,32]$.

Figure 2. Number of seropositive animals according to the General Organization of Veterinary Service (GOVS, 2012).

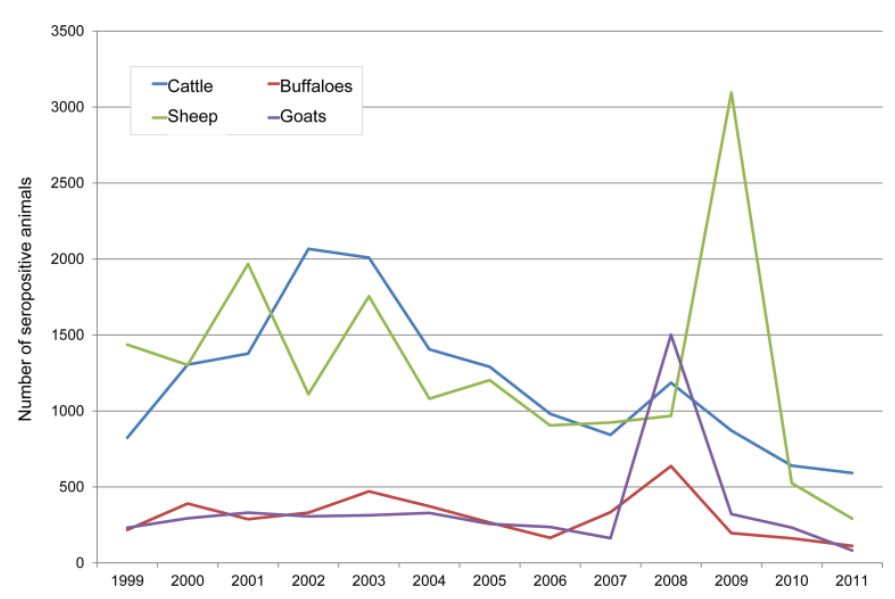


Table 1. Prevalence of brucellosis in Egypt from January 1999 through December 2011 based on reports from the General Organization of Veterinary Services

\begin{tabular}{|c|c|c|c|c|c|c|c|c|c|c|c|c|c|c|c|c|c|c|}
\hline & \multicolumn{4}{|c|}{ Cattle } & \multicolumn{4}{|c|}{ Buffalo } & \multicolumn{4}{|c|}{ Sheep } & \multicolumn{4}{|c|}{ Goat } & \multicolumn{2}{|c|}{ Total } \\
\hline Year & $\begin{array}{l}\text { Total no. } \\
\text { in Egypt }\end{array}$ & $\begin{array}{l}\text { No. } \\
\text { tested }\end{array}$ & $\begin{array}{l}\text { No. } \\
+ \text { ve }\end{array}$ & $\begin{array}{l}\%+v e \\
\text { from } \\
\text { tested }\end{array}$ & $\begin{array}{l}\text { Total no. } \\
\text { in Egypt }\end{array}$ & $\begin{array}{l}\text { No. } \\
\text { tested }\end{array}$ & $\begin{array}{l}\text { No. } \\
+\mathrm{ve}\end{array}$ & $\begin{array}{c}\% \\
+\mathrm{ve} \\
\text { from } \\
\text { tested }\end{array}$ & $\begin{array}{l}\text { Total no. } \\
\text { in Egypt }\end{array}$ & $\begin{array}{l}\text { No. } \\
\text { tested }\end{array}$ & $\begin{array}{l}\text { No. } \\
+\mathrm{ve}\end{array}$ & $\begin{array}{c}\%+v e \\
\text { from } \\
\text { tested }\end{array}$ & $\begin{array}{l}\text { Total no. } \\
\text { in Egypt }\end{array}$ & $\begin{array}{l}\text { No. } \\
\text { tested }\end{array}$ & $\begin{array}{l}\text { No. } \\
\text { +ve }\end{array}$ & $\begin{array}{c}\%+v e \\
\text { from } \\
\text { tested }\end{array}$ & $\begin{array}{l}\text { Total } \\
\text { tested }\end{array}$ & $\begin{array}{c}\%+v e \\
\text { from } \\
\text { tested }\end{array}$ \\
\hline 1999 & $3,417,580$ & 108,622 & 824 & 0.76 & $3,329,700$ & 62,900 & 218 & 0.35 & $4,390,730$ & 62,151 & 1,437 & 2.31 & $3,308,150$ & 17,875 & 232 & 1.30 & 251,548 & 1.08 \\
\hline 2000 & $3,529,720$ & 145,750 & 1,305 & 0.90 & $3,379,410$ & 66,109 & 391 & 0.59 & $4,469,130$ & 68,342 & 1,303 & 1.91 & $3,424,760$ & 16,685 & 294 & 1.76 & 296,886 & 1.11 \\
\hline 2001 & $3,801,070$ & 152,436 & 1,378 & 0.90 & $3,532,240$ & 81,302 & 288 & 0.35 & $4,671,240$ & 78,310 & 1,967 & 2.51 & $3,497,000$ & 21,912 & 331 & 1.51 & 333,960 & 1.19 \\
\hline 2002 & $4,081,000$ & 162,309 & 2,067 & 1.27 & $3,717,000$ & 67,802 & 331 & 0.49 & $5,105,000$ & 99,466 & 1,111 & 1.12 & $3,582,000$ & 23,560 & 307 & 1.30 & 353,137 & 1.08 \\
\hline 2003 & $4,227,000$ & 168,281 & 2,009 & 1.19 & $3,777,000$ & 67,588 & 471 & 0.70 & $4,939,000$ & 79,565 & 1,755 & 2.21 & $3,811,000$ & 29,576 & 314 & 1.06 & 345,010 & 1.32 \\
\hline 2004 & $4,369,000$ & 154,984 & 1,406 & 0.91 & $3,845,000$ & 56,041 & 373 & 0.67 & $5,043,000$ & 68,122 & 1,081 & 1.59 & $3,889,000$ & 25,719 & 329 & 1.28 & 304,866 & 1.05 \\
\hline 2005 & $4,485,000$ & 174,673 & 1,291 & 0.70 & $3,885,000$ & 69,931 & 266 & 0.38 & $5,232,000$ & 69,571 & 1,203 & 1.73 & $3,915,000$ & 25,325 & 257 & 1.01 & 339,500 & 0.87 \\
\hline 2006 & $4,610,000$ & 199,954 & 982 & 0.49 & $3,937,000$ & 61,595 & 165 & 0.27 & $5,385,000$ & 71,929 & 905 & 1.26 & $3,960,000$ & 26,689 & 237 & 0.89 & 360,167 & 0.64 \\
\hline 2007 & $4,932,660$ & 161,206 & 843 & 0.52 & $4,104,810$ & 68,548 & 334 & 0.49 & $5,467,470$ & 68,171 & 924 & 1.36 & $4,210,710$ & 33,791 & 163 & 0.48 & 331,716 & 0.68 \\
\hline 2008 & $5,023,160$ & 182,248 & 1,186 & 0.65 & $4,052,650$ & 59,080 & 637 & 0.40 & $5,498,030$ & 106,215 & 968 & 0.91 & $4,473,490$ & 46,703 & 1502 & 3.22 & 294,246 & 0.99 \\
\hline 2009 & $4,524,950$ & 175,750 & 871 & 0.50 & $3,838,720$ & 51,924 & 196 & 0.38 & $5,591,850$ & 84,798 & 3,095 & 3.65 & $4,139,260$ & 44,023 & 322 & 0.73 & 356,495 & 1.25 \\
\hline 2010 & $4,728,720$ & 183,490 & 640 & 0.30 & $3,818,240$ & 53,783 & 162 & 0.30 & $5,529,530$ & 66,412 & 525 & 0.79 & $4,174,990$ & 39,143 & 233 & 0.60 & 342,828 & 0.5 \\
\hline 2011 & $4,803,000$ & 167,188 & 592 & 0.35 & $3,800,000$ & 55,986 & 112 & 0.20 & $5,488,000$ & 65,849 & 292 & 0.44 & $4,207,400$ & 31,772 & 83 & 0.26 & 320,795 & 0.33 \\
\hline
\end{tabular}

Table 2. Origin of Brucella isolates in Egypt

\begin{tabular}{|c|c|c|c|c|c|c|c|c|c|c|}
\hline & & B. melitensis & & & & & & & & B.suis \\
\hline Location & B. melitensis & bv3 & bv2 & bv1 & rev.1 & B. abortus & bv1 & bv3 & bv7 & B. suis bv1 \\
\hline Cairo & & {$[49,50,73]$} & & & & & [49] & & & \\
\hline Qalyobia & & {$[22,49,50,73]$} & & & & & [49] & & & \\
\hline Menufiya & [76] & {$[22,26,33,34,44,49,73]$} & [73] & & [33] & & [49] & [44] & [44] & \\
\hline Gharbia & & {$[26,34,49,73]$} & [73] & & & & [49] & & & \\
\hline Behira & & {$[20,22,26,34,49,73]$} & & & & & [49] & & & \\
\hline Alexandria & & {$[22,49,73,74]$} & & & & & [49] & & & \\
\hline Kafrelsheikh & & {$[17,34,44,, 48,50,49,73,74]$} & & & & & [49] & [44] & [44] & \\
\hline Demiatta & & {$[49,73]$} & & & & & [49] & & & \\
\hline Dakahlia & & {$[34,50]$} & & & & & [74] & & & \\
\hline Sharkia & & {$[29,41,49,73]$} & & & & & {$[49,77]$} & [77] & & \\
\hline Suez & & {$[49,73]$} & & & & & [49] & & & \\
\hline Ismalia & [42] & & & & & & & & & \\
\hline Port-Said & & {$[49,73]$} & & & & & [49] & & & \\
\hline Matroh & & [73] & & & & & & & & \\
\hline Giza & {$[16,42]$} & {$[22,25,49,50,73]$} & & [73] & & & {$[25,49]$} & & & \\
\hline Fayoum & & {$[26,44,49]$} & & & & [54] & [49] & [44] & [44] & \\
\hline Beni-Suef & {$[16,40]$} & {$[22,44,73]$} & & & & [40] & & [44] & [44] & \\
\hline El-Minia & & {$[55,73,74]$} & & & & & & & & \\
\hline Assiut & & {$[22,31,35,49,72,73]$} & & & & & [49] & & & \\
\hline Sohag & {$[16]$} & {$[26,73]$} & & & & & & & & \\
\hline Qina & & [73] & & & & & & & & \\
\hline Aswan & & {$[26]$} & & & & & & & & \\
\hline Different locations in Egypt & & {$[39,43,44,51,53,75]$} & & & & & [53] & {$[51,75]$} & {$[44,51,53,58,75]$} & {$[68]$} \\
\hline
\end{tabular}


Data obtained by sampling animals in slaughterhouses have to be considered biased, as brucellosis-seropositive animals ought to be slaughtered by law. Studies on camels $(n=12)$ demonstrated a high seroprevalence in these animals. It should be noted that camels are imported from Sudan, where brucellosis is endemic.

The prevalence of brucellosis in cattle, buffaloes, sheep, and goats was generally higher in Beni-Suef governorate than in other governorates in upper Egypt $[11,22]$. In the Delta region, the highest prevalence was reported in Behira governorate. Inadequate preventive measures and uncontrolled transport between Egyptian governorates to and from animal markets may play an important role in the incidence of brucellosis.

\section{Culture and biotyping}

Isolation of Brucella is still the gold standard for brucellosis diagnostics, but it has several drawbacks such as hands-on time and low sensitivity, especially in chronic cases. Handling of culture material poses a high risk of infection to the operator. Our analysis shows that this technique is restricted to a few laboratories in Egypt. A total of 35 publications on isolation or biotyping of Brucellae were selected for review. In general, these studies were done within outbreak investigations. Most authors of theses described the techniques used very clearly and comprehensively so that results could easily be checked for plausibility. Strains isolated were regularly determined by investigating $\mathrm{CO}_{2}$ requirement, $\mathrm{H}_{2} \mathrm{~S}$ production, growth in the presence of thionin and basic fuchsin dyes, agglutination test with monospecific $\mathrm{A}$ and $\mathrm{M}$ antisera, and phage lysis test. In contrast, only 15 articles published between 1986 and 2012 followed the complete method of biotyping. Brucella strains were isolated from milk, blood, vaginal discharge, and aborted fetuses of infected cattle, buffaloes, sheep, goats, and camels $[22,25,72,73]$, and also from organs including liver, spleen, lung, kidneys, heart, and lymph nodes $[22,40,55]$. The rationales for sampling, sampling strategy, or statistics of sampling were missing. Hence, the presence of $B$. melitensis bv 1, 2, 3 and B. abortus bv 1,3 , and 7 was unambiguously demonstrated. $B$. melitensis bv 3 is the predominant pathovar isolated independent from the host species and bv 1 and 2 were described in a single study in 2004 only. Isolates of $B$. melitensis originated from all farm animal species and also from rats. Vaccine strain Rev. 1 was isolated from ewes in Menufiya in 2007. Only 12 publications describe the presence of B. abortus in Egypt; bv 3 was found by four author groups in 1986, 1987, and 1990. Five publications also mentioned bv 7, which was later on removed from the nomenclature list as being erroneous. The presence of $B$. abortus bv 3 has yet to be confirmed. Isolates were obtained from cattle and buffaloes and the erroneous $B$. abortus bv 7 was obtained from a camel one instance. Human pathogenic $B$. suis bv 1 was isolated from pigs in 1996. No Brucellae isolates exist from Red Sea, New Valley, Luxor, North Sinai, or South Sinai. All data are shown in Table 2.

Isolation of B. melitensis from cattle and buffaloes was attributed to mixed rearing of sheep and goats with cattle or buffaloes on holdings or in one flock, contamination of pastures by infected sheep and goats, and spreading of disease by these animals to new areas [22]. However, no proof for this assumption was made via genotyping of strains or tracing back investigations. Alarming is the fact that $B$. melitensis bv 3 was also isolated from 4 out of 65 semen samples from bulls $(6.2 \%)$ and 3 out of $55(5.5 \%)$ samples from rams, respectively, at the Animal Reproduction Research Institute, Giza [43]. Venereal transmission may be responsible for maintaining a bovine brucellosis cycle based on unhygienic serving methods (i.e., that one bull serves cows of various holdings in different neighboring villages). As a consequence, artificial insemination and semen collection have to be done under strict precautions.

\section{Molecular diagnostics}

Because of the shortcomings of culture, the use of new diagnostic techniques for the direct detection of Brucellae was attempted, although no biovar-specific PCR assays exist. Authors of only 15 publications from 1986 to 2012 used PCR. The sensitivity of PCR proved to be higher than cultivation [78], and even small numbers of Brucellae were detected in samples [25]. B. melitensis DNA was found in the semen of bulls and rams [43] and in the milk of cattle, buffaloes, sheep, and goats in Menufiya, Gharbia, Behira, Fayoum, Aswan, Beni-Suef, and Sohag governorates $[16,26]$. Montasser et al. and Zahran found DNA of $B$. melitensis in tissue samples of cattle, sheep, and goats in Assiut and El-Minia governorates, respectively [35,55]. B. abortus DNA was detected and identified in Fayoum governorate from seropositive cattle [54]. In Menufiya governorate, the use of PCR restriction fragment length polymorphism (PCR-RFLP) identified four strains of $B$. melitensis bv 3 and two strains of $B$. melitensis Rev. 1 vaccine in tissue samples collected 
from six seropositive ewes [33]. The first comprehensive report describing the presence of $B$. melitensis DNA in camel milk dates back to 2002 when it was amplified from a milk sample from Giza governorate [25]. B. melitensis DNA was found again in Aswan and Sohag governorates in both milk and serum of camels [26]. PCR is a sensitive tool for the diagnosis of brucellosis. Recently, Wareth et al identified B. abortus and B. melitensis DNA in bovine milk collected from apparently healthy animals by species-specific IS711 RT-PCR [79]. These results highlight a special public health hazard for farmers and nomadic peoples who encourage the drinking of raw milk from camels as they believe that it has a soothing and therapeutic effect against digestive tract diseases and liver infections [78].

\section{Environmental contamination with Brucellae}

Significant environmental contamination has to be assumed due to local husbandry methods and the lack of effective carcass disposal. Nile catfish have been found to be infected with $B$. melitensis, especially in small tributaries of Nile canals in the governorates of Kafrelsheikh, Menufiya, Gharbiya, and Dakahlia in the Nile Delta region. It was isolated from 5.8\%, 4.2\%, $5.8 \%$, and $13.3 \%$ of liver, kidney, spleen samples and skin swabs, respectively; it was not isolated from samples of farmed fish [34]. It is speculated that disposal of animal waste (carcasses, milk, aborted and parturition materials) into the Nile or its canals plays an important role in the transmission of Brucella and is also the reason for the high incidence in these regions. Farmers also wash their animals in these canals or try to reduce the body temperature of diseased animals in the Nile, which may contribute to spreading of Brucellae. Moreover, B. melitensis bv 3 was also isolated from rats [44]. Only one study reported Brucellae in fish. This fact is interesting and should be investigated further in the future. The presence of Brucellae in rat and fish indicates high environmental contamination, which is alarming.

\section{Surveillance program}

Despite 30 years of work and efforts of the General Organization of Veterinary Services to overcome brucellosis in Egypt by testing female cattle and buffaloes older than six months of age and slaughtering serologically positive animals, the vaccination of calves with $B$. abortus S19 and adults with BR51 vaccines and small ruminants with $B$. melitensis Rev 1 vaccine [11], the results are disappointing and brucellosis is still endemic among humans and ruminants in Egypt. Modeling of the currently applied measures suggests that, at best, $4 \%$ of the animal stocks (but not more than 5\%) are included in the control program [80]. Our data implies that even this number is overestimated. Several authors proposed that, hotspots are located in the Delta region and in upper Egypt, along the River Nile and south of the Delta containing 32\% of the Egyptian large ruminant and $39 \%$ of the small ruminant stocks which are often kept in small mixed herds owned by single households [81]. The assumption of hotspots needs further confirmation. A simple sampling bias might be seen. Various authors linked the limited success of the control program to improper diagnosis and spreading of the disease at large animals markets where different animal species of unknown health status from different towns and governorates intermix. Additionally, small ruminant flocks present in high numbers in Egypt are highly migratory [22]. Low compensation for owners results in slaughtering of only $0.2 \%$ of seropositive animals [18]. Emotional attachment of owners to animals that they had kept for long time may also be a reason for their unwillingness to slaughter seropositive animals [82].

\section{Summary}

In summary, it can only be assumed that brucellosis is prevalent nationwide in all farm animal species, in the environment, and in carrier hosts such as rats. The predominant occurrence of $B$. melitensis bv 3 in bovines is in contrast to Egyptian reports published before 1980 which had described the classic epidemiology of brucellosis with $B$. abortus in cattle and buffaloes and $B$. melitensis in small ruminants, respectively. The question must be raised whether a $B$. melitensis clone was able to cross species barriers and was able to establish a permanent reservoir in cattle and buffaloes. A husbandry system favoring mixed populations of cattle, buffaloes, sheep and goats, limited success of the official control program due to unrealistic high sampling numbers, and poor compliance of livestock farmers has contributed to the emergence of brucellosis in Egypt [18]. The need for a nationwide survey to genotype circulating Brucellae is obvious. Thus, the epidemiologic situation of brucellosis in Egypt is cryptic and needs clarification. Consequently, cultivation and biotyping of Brucella isolates has to be made available for all governorates to monitor the effect of control programs and to trace back outbreaks. Future seroprevalence studies must meet scientific standards. The current control program is ineffective and a new strategy to combat brucellosis 
has to be developed, tailored for the parlous situation of Egypt farmers.

The need for an efficient animal registration and marking system is obvious. The sale of Brucellainfected animals in the open market is increasing in Egypt. The introduction of a Brucella-infected animal into a herd can lead to spread of the infection to the whole herd, causing economic losses. Markets should be controlled by veterinarians and compensation for those selling animals should be satisfied to prevent infected animals from being sold [83]. Slaughter has to be replaced by culling and safe disposal of carcasses to avoid human infection or pollution of the environment. The measures of the control program have to be made mandatory, and a reasonable system of compensation has to be implemented to enhance acceptance. The basic tools for a program such as an adequate number of public veterinarians for field work and state laboratories capable of serological techniques are already available. Information technology solutions and further logistic means such as animal identification techniques are in place in many countries and may be adapted to the special needs of a country like Egypt.

\section{Acknowledgements}

We would further like to thank the DAAD (German Academic Exchange Service) for financial support of G.W., grant no. A/11/92495, and the Egyptian Ministry of Higher Education for partial funding. The funders had no role in study design, data collection and analysis, decision to publish, or preparation of the manuscript.

\section{References}

1. Gorvel J-P (2008) Brucella: a Mr "Hide" converted into Dr Jekyll. Microbes Infect 10: 1010-1013.

2. Godfroid J, Scholz H, Barbier T, Nicolas C, Wattiau P, Fretin D, Whatmore AM, Cloeckaert A, Blasco JM, Moriyon I, Saegerman C, Muma JB, Al Dahouk S, Neubauer H, Letesson JJ (2011) Brucellosis at the animal/ecosystem/human interface at the beginning of the 21 st century. Prev Vet Med 102: 118-131.

3. Morgan W (1984) Brucella classification and regional distribution. Dev Biol Stand 56: 43-53.

4. Scholz H, Hubalek Z, Sedlácek I, Vergnaud G, Tomaso H, Al Dahouk S, Melzer F, Kämpfer P, Neubauer H, Cloeckaert A, Maquart M, Zygmunt MS, Whatmore AM, Falsen E, Bahn P, Göllner C, Pfeffer M, Huber B, Busse HJ, Nöckler K (2008) Brucella microti sp. nov.isolated from the common vole Microtus arvalis. Int J Syst Evo Microbiol 58: 375-382.

5. Scholz HC, Nöckler K, Göllner C, Bahn P, Vergnaud G Tomaso H, Al Dahouk S, Kämpfer P, Cloeckaert A, Maquart M, Zygmunt MS, Whatmore AM, Pfeffer M, Huber B, Busse HJ, De BK (2010) Brucella inopinata sp. nov., isolated from a breast implant infection. Int J Syst Evol Microbiol 60: 801808.

6. Holt H, Eltholth M, Hegazy Y, El-Tras W, Tayel A, Guitian J (2011) Brucella spp. infection in large ruminants in an endemic area of Egypt: Cross-sectional study investigating seroprevalence, risk factors and livestock owner's knowledge, attitudes and practices (KAPs). BMC Public Health 11: 341350 .

7. Neubauer H (2010) Brucellosis: New demands in a changing world. Prilozi 1: 209-217.

8. WHO (2006) The control of neglected zoonotic diseases. In report of the first meeting on the control of neglected zoonotic diseases, WHO and Department for International Development-Animal Health Programme (DFID-AHP), with the participation of FAO and OIE 20-21 September 2005. Edited by: WHO/SDE/FOS. WHO Headquarters, Geneva; 2006.

9. Staszkiewicz J, Lewis CM, Colville J, Zervos M, Band J (1991) Outbreak of Brucella melitensis among microbiology laboratory workers in a community hospital. J Clin Microbiol 29: 287-290.

10. Pappas G, Papadimitriou P (2007) Challenges in Brucella bacteraemia. Int J Antimicrob Agents 1: 29-31.

11. Refai M (2002) Incidence and control of brucellosis in the Near East region. Vet Microbiol 90: 81-110.

12. Hassanain NA, Ahmed WM (2012) Sero-prevalence of brucellosis in Egypt with emphasis on potential risk factors. World Journal of Medical Sciences 7: 81-86.

13. Nicoletti P (2010) Brucellosis: past, present and future. Prilozi 31: 21-32.

14. Al Dahouk S, Nöckler K, Scholz HC, Tomaso H, Bogumil R, et al. (2006) Immunoproteomic characterization of Brucella abortus 1119-3 preparations used for the serodiagnosis of Brucella infections. J of Immunol Method 309: 34-47.

15. Alton GG, Jones LM, Angus RD, Verger JM (1988) Techniques for the brucellosis laboratory, 17-62. Institut tional de la Recherche Agronomique, Paris.

16. Abd Al-Azeem MW, Elmalt LM, Zain El Abdein AED, Sayed HH (2012) Molecular and serological studies on detection of Brucella species in cattle and buffaloes. J Pharm Biomed Sci 2: 16-24. 
17. Abdel-Razik K, Desouky H, Ahmed W (2007) Investigations on brucellosis in Egyptian baladi does with emphasis on evaluation of diagnostic techniques. Pak J Biol Sci 10: 342348.

18. Hegazy YM, Molina-Flores B, Shafik H, Ridler AL, Guitian FJ (2011) Ruminant brucellosis in Upper Egypt (2005-2008) Prev Vet Med 101: 173-181.

19. Hegazy YM, Moawad A, Osman S, Ridler A, Guitian J (2011) Ruminant brucellosis in the Kafr El Sheikh governorate of the Nile delta, Egypt: Prevalence of a neglected zoonosis. PLoS Negl Trop Dis 5: e944. doi:910.1371/journal.pntd.0000944.

20. Abdel-Hakiem EH (2000) The role of cow's raw milk in transmission of brucellosis. Tropenlandwirt, Beiheft 69: 3341.

21. Refai M, El-Gibaly S, Salem TF (1988) Brucellosis in cows and buffaloes in Egypt. Proceedings of the second world buffalo congress, India, 12-16 December 4: 27-29.

22. Samaha H, Al-Rowaily M, Khoudair RM, Ashour HM (2008) Multicenter study of brucellosis in Egypt. Emerg Infect Dis 14: 1916-1948.

23. Samaha H, Mohamed TR, Khoudair RM, Ashour HM (2009) Serodiagnosis of brucellosis in cattle and humans in Egypt. Immunobiology 214: 223-226.

24. Amin M, Ahmed S, Zaki H, Ismail R (2012) Serological and molecular studies on the diagnosis of bovine brucellosis. Nature and Science 10: 68-76.

25. Hamdy MER, Amin AS (2002) Detection of Brucella species in the milk of infected cattle, sheep, goats and camels by PCR. Vet J 163: 299-305.

26. Ibrahim AK, AbdelAll AA, Amin AS (2012) Long-term diagnostic studies for detection of Brucella spp. in milk samples. Global Veterinaria 8: 54-61.

27. Kaoud H, Zaki M, El-Dahshan A, Nasr S (2010) Epidemiology of brucellosis among farm animals. Nature and Science 8: 190-197.

28. El-Boshy M, Abbas H, El-Khodery S, Osman S (2009) Cytokine response and clinicopathological findings in Brucella infected camels (Camelus dromedarius). Veterinarni Medicina 54: 25-32.

29. El-Sayed ME, El-Newishy AMA, Hussein MN, EL-Ged AMS, EL-Basionny AA, et al. (2011) Serological studies of man on animal brucellosis in Sharkia governorate. BVMJ Special Issue: 23-35.

30. Abdel-Hafez SM, El-Razik KAA, Hassan HM, Gad I (2011) Comparative diagnosis of ovine brucellosis using single step blood-PCR with old and new serological tools. Afr J Microbiol Res 5: 3976-3980.

31. Affi MM, Abdul-Raouf UM, El-Bayoumy EM, Montasser AM, Mohamad HA (2011) Isolation and biotyping of Brucella melitensis from Upper Egypt. Journal of American Science 7: 653-659.

32. El-Sherbini A, Kabbash I, Schelling E, Shennawy SE, Shalapy N, et al. (2007) Seroprevalences and local variation of human and livestock brucellosis in two villages in Gharbia governorate, Egypt. Trans R Soc Trop Med Hyg 101: $923-$ 928.

33. Helmy NM, Zaki HM, Adawy SS (2007) Identification and differentiation of Brucella melitensis Rev. 1 vaccine and $B$. melitensis biovar 3 field isolates in Egypt by serological and PCR-RFLP techniques. J Appl Sci Res 3: 841-847.

34. El-Tras W, Tayel A, Eltholth M, Guitian J (2010) Brucella infection in fresh water fish: Evidence for natural infection of
Nile catfish, Clarias gariepinus, with Brucella melitensis. Vet Microbiol 141: 321-325.

35. Montasser A, Affi M, El-Bayoumy E, Abdul-Raouf U, Mohamad H (2011) Efficiency of serological tests for detection of brucellosis in ruminant at south provinces of Egypt. Global Veterinaria 6: 156-161.

36. Abdel-Khalek M, Ramadan K, Hazem S, Khairy E (2012) Evaluation of immunochromatographic assay for serodiagnosis of Brucella among cattle, sheep and goats in Egypt. Global Veterinaria 8: 511-518.

37. Abdel-Moghney A (2004) A preliminary study on brucellosis on camels at Behira province. Ass Univ Bull Environ Res 7: 39-43.

38. Barakat A, Fadaly H, Shaapan R, Khalil F (2011) Occupational health hazard of Egyptian employees in contact with wastage nourished swine. J Am Sci 7: 808-813.

39. Abdel-Razik K, Ismail E, Youssef H, Hashad M (2008) Diagnosis of brucellosis in dairy animals using nested polymerase chain reaction. Int J Dairy Sci 3: 55-62.

40. Fatma H, Mahdey E (2010) Incidence of Brucella species in slaughtered food animals and its edible offal at Beni-Suef, Egypt. Global Veterinaria 5: 248-254.

41. Soror A, Nibal A, El-Razik K (2009) Detection of Brucella melitensis by AMOS-PCR assay and histopathological findings in tissue of serologically positive buffalo-cows. Global Veterinaria 3: 232-238.

42. Ahmed Y, Soker S, Desoky H, Ghazi Y, Amin A, et al. (2010) Pathological and molecular studies on mammary gland and supramammary lymph nodes of naturally Brucella infected Buffalo-cow. J Reprod Fertil 1: 33-40.

43. Amin A, Hamdy M, Ibrahim A (2001) Detection of Brucella melitensis in semen using the polymerase chain reaction assay. Vet Microbiol 83: 37-44.

44. Abdel-Aal HIH (1987) Studies on brucellosis in animals. PhD thesis, Department of Animal and Fish diseases; Fac of Vet Med, Cairo University, Egypt.

45. Abdel-Hamid N, Ebeid M, Arnaout F, Elgarhy M, Elbauomy E, et al. (2012) Serological and bacteriological monitoring of ruminant brucellosis in seven governorates with control program follow-up in three cattle farms. BVMJ 23: 254-263.

46. Ali M, Makar N, Seddek S (2005) Serological study of brucellosis on camels in Assiut and New-Valley governorates. Assiut Vet Med J 51: 158-164.

47. Ammar K (1990) Brucellosis in cattle. MVSc thesis, Department of Infectious Diseases; Fac of Vet Med, Zagazig University, Egypt.

48. Khoudair R, Ibrahim E, Saker G, Hafez M (2009) Clinicodiagnostic and pathological studies on cattle and buffaloes suffering from brucellosis and tuberculosis in Kafrelsheikh governorate. Egypt J Comp Path and Clinic Path 22: $148-174$.

49. Hamdy M (1992) Epidemiological studies on Brucella melitensis in dairy animals and man. PhD thesis, Department of Hygiene, Feeding and Animal Ethology; Fac of Vet Med, Cairo University, Egypt.

50. El-Bauomey E (1989) Some studies on brucellosis in sheep and goats. PhD thesis, Department of Veterinary Medicine; Fac. of Vet. Med., Cairo University, Egypt.

51. Salem T (1987) Biological typing of local Brucella species isolated from farm animals. PhD thesis, Department of Microbiology ; Fac of Vet Med, Cairo University, Egypt. 
52. Abou-Zaid A, Mehanna A (1998) Evaluation of some diagnostic tests for brucellosis in cattle. Vet Med J Giza 46: 319-328.

53. El-Seedy F, Radwan A, El-Shabrawy M (2000) Serological and bacteriological investigations on Brucella infection in one humped camels (Camelus dromedarius ) in Egypt. Vet Med J Giza 48: 83-89.

54. Moawad A, Osman S (2006) Polymerase chain reaction (PCR) as an accurate technique for the diagnosis of brucellosis in cattle. Assiut Vet Med J 52: 154-169.

55. Zahran E (2004) Bacteriological and serological studies on Brucella microorganisms in farm animals in El-Minia governorate. $\mathrm{PhD}$ thesis, Department of Bacteriology; Fac of Vet Med, Beni-Suef University; Egypt.

56. Seddek S (1999) Serological studies on Brucella infection in cattle, sheep and goats in Assiut governorate. Assiut Vet Med J 42: 216-227.

57. Abdel-Razek A, Abd-Elghaffar S, Fouad I (2006) Serological and pathological studies on endemic brucellosis in sheep and goat in Assiut and Sohag provinces. Assiut Vet Med J 52: 383-398.

58. Nada A, Ismail E, Shawkat M, Gibaly S, Barsoum S (1991) Studies on brucellosis in camels in Egypt. Egyptian J of Vet Sci 28: 91-101.

59. Mahmoud A (1991) Prevalence of brucellosis among farm animals in Kafrelsheikh governorate [Egypt]. Assiut Vet Med J 23: 173-178.

60. Fahmy B, Zaki H (2006) Serological tests and biochemical profiles in camels infected with brucellosis. Vet Med J Giza 54: 379-403.

61. Oraby N, Ismail A, Hussein A, Elias A, Abdel-Kader H (2007) The use of ELISA [Enzyme-Linked Immmosorbent Assay] for diagnosis and epidemiology of Brucella infection in some farm animals and humans in Assiut governorate. Vet Med J Giza 55: 851-865.

62. Al-Gaabary M, Mourad M (2004) Seroprevalence of camel brucellosis in the east governorate of Assiut, Egypt. Assiut Vet Med J 50: 70-74.

63. El Bassiony T, El Prince E, El Abdeen S, Sadek O (2007) Diagnosis of Brucella infection in dairy cattle with serological tests in Assiut governorate. Assiut Vet Med J 53: 167-180.

64. Bassiony M (2010) Diagnosis of brucellosis in low titred buffaloes. Vet Med J Giza 58: 393-401.

65. El-Naggar A, Amin M, Youssef R, Mahmoud M, Elkattan A (2006) Studies on some bacterial infections of camels in Halaieb, Shalateen and Abou-Ramad triangle. Vet Med J Giza 54: 701-714.

66. Abdel-Kader H (1996) Serological study of caprine brucellosis in Assiut governorate. Assiut Vet Med J 36: 9-16.

67. Abdel-Hafeez M (1996) A serological study on brucellosis infection among cattle in Assiut governorate. Assiut Vet Med J 36: 1-8.

68. Ibrahim S (1996) Studies on swine brucellosis in Egypt. J Egypt Vet Med Ass 56: 1-12.

69. Ali M (1997) Serodiagnostic study of sheep brucellosis in Assiut governorate. Assiut Vet Med J 36: 167-174.
70. Ahmed T, El-Aal A (1996) Investigations on brucellosis in a large dairy buffalo herd. Assiut Vet Med J 35: 105-113.

71. Omran E (2007) Epidemiological studies on brucellosis in farm animals as a source of infection to man in New-Valley governorate. MVSc thesis, Department of Zoonoses; Fac of Vet Med; Assiut University; Egypt.

72. Ali H, Ibrahim S, Thabet A (1993) Some studies on brucellosis in water buffaloes during time of abortion at Assiut governorate. Assiut Vet Med J 29: 143-150.

73. Sayour A (2004) The use of recent bacteriological techniques in the differentiation of Brucella group of micro-organisms. $\mathrm{PhD}$ thesis, Department of Microbiology; Fac of Vet Med, Cairo University; Egypt.

74. Sayour A (1995) An approach towards the use of some unconventional serological tests for the diagnosis of brucellosis. MVSc thesis, Department of Microbiology; Fac of Vet Med, Cairo University; Egypt.

75. Salem A, Hosein H (1990) Brucella strains prevalent in Egypt. Assiut Vet Med J 22: 160-163.

76. Atwa E, Rady F (2007) Bacteria and fungi associated with abortion in sheep and goat in Menoufiea governorate. Assiut Vet Med J 53: 326-349.

77. Abdel Galil Y, Enany, El-kenawy, Menazi A (1986) Bacteriological studies on five isolates of Brucella abortus in Sharkia governorate. Zagazig Vet J xiv: 215-223.

78. Leal-Klevezas D, Martinez-Vazquez I, Lopezmerino A, Martinez-Soriano J (1995) Single step PCR for detection of Brucella spp. from blood and milk of infected animals. J Clin Microbiol 33: 3087-3090.

79. Wareth G, Melzer F, Elschner MC, Neubauer H, Roesler U (2014) Detection of Brucella melitensis in bovine milk and milk products from apparently healthy animals in Egypt by real-time PCR. J Infect Dev Ctries 8:1339-1343.

80. Hegazy Y, Ridler A, Guitian F (2009) Assessment and simulation of the implementation of brucellosis control programme in an endemic area of the Middle East. Epidemiol Infect 137: 1436-1448.

81. Aidaros H (2005) Global perspectives - the Middle East: Egypt. Rev Sci Tech 24: 589-596.

82. McDermott J, Arimi S (2002) Brucellosis in sub-Saharan Africa: epidemiology,control and impact. Vet Microbiol 90: 111-134.

83. Henderson R (1969) Cause for concern. Dealing in brucellainfected cattle. Br Med J 4: 550.

\section{Corresponding author}

Gamal Wareth

Friedrich-Loeffler-Institut, Federal Research Institute for Animal Health

Institute of Bacterial Infections and Zoonoses

Naumburger Str. 96a, 07743 Jena, Germany

Phone: +49 036418042296

Mobile: +49 015779564050

Email: gamalwareth@hotmail.com; gamal.wareth@fli.bund.de

Conflict of interests: No conflict of interests is declared. 


\section{Supplementary Items}

Supplementary Table 1. Serology data arranged in tables according to time of publication

\begin{tabular}{|c|c|c|c|c|c|c|c|c|}
\hline Reference & $\begin{array}{l}\text { Serology } \\
\text { tests }\end{array}$ & $\begin{array}{l}\text { Animals } \\
\text { tested }\end{array}$ & $\begin{array}{l}\text { Sample } \\
\text { no. }\end{array}$ & $\begin{array}{l}\text { Sample } \\
\text { type }\end{array}$ & Prevalence & Location & Isolates & Inclusion criteria \\
\hline$[16]$ & $\begin{array}{l}\text { BAPAT }^{*}, \mathrm{RBT}^{* *} \\
\text { TAT }^{* * *}, \operatorname{Riv}^{* * * *}{ }^{* * *} \\
\text { MRT }^{* * * * *} \\
\text { PCR }^{* * * * * *}\end{array}$ & $\begin{array}{l}\text { Cows } \\
\text { Buffaloes } \\
\text { Cows } \\
\text { Buffaloes }\end{array}$ & $\begin{array}{l}32 \\
18 \\
96 \\
54\end{array}$ & $\begin{array}{l}\text { Serum } \\
\text { Serum } \\
\text { Milk } \\
\text { Milk }\end{array}$ & $\begin{array}{l}100 \% \\
100 \% \\
87.5 \% \\
83.3 \%\end{array}$ & $\begin{array}{l}\text { Sohag, Beni-Suef, } \\
\text { Giza }\end{array}$ & $\begin{array}{l}B . \\
\text { melitensis }\end{array}$ & Outbreak investigation \\
\hline [26] & $\begin{array}{l}\text { RBT } \\
\text { MRT, ELISA } \\
\text { PCR, DBH }\end{array}$ & $\begin{array}{l}\text { Cows } \\
\text { Buffaloes } \\
\text { Sheep } \\
\text { Goats } \\
\text { Camels } \\
\text { Cows } \\
\text { Buffaloes } \\
\text { Sheep } \\
\text { Goats } \\
\text { She- } \\
\text { camels }\end{array}$ & $\begin{array}{l}660 \\
482 \\
194 \\
198 \\
151 \\
302 \\
321 \\
73 \\
121 \\
64\end{array}$ & $\begin{array}{l}\text { Serum } \\
\text { Serum } \\
\text { Serum } \\
\text { Serum } \\
\text { Serum } \\
\text { Milk } \\
\text { Milk } \\
\text { Milk } \\
\text { Milk } \\
\text { Milk }\end{array}$ & $\begin{array}{l}45.8 \% \\
66.6 \% \\
37.6 \% \\
61.1 \% \\
42.1 \% \\
51 \% \\
49.8 \% \\
56.2 \% \\
36.4 \% \\
34.4 \%\end{array}$ & $\begin{array}{l}\text { Menufiya, Gharbia, } \\
\text { Behira, Fayoum, } \\
\text { Aswan, Sohag }\end{array}$ & $\begin{array}{l}B . \\
\text { melitensis } \\
\text { bv } 3\end{array}$ & $\begin{array}{l}\text { Outbreak investigation and } \\
\text { trade (camel) }\end{array}$ \\
\hline$[12]$ & $\begin{array}{l}\text { STAT } \\
\text { RBT }\end{array}$ & $\begin{array}{l}\text { Cattle } \\
\text { Buffaloes } \\
\text { Camel } \\
\text { Mares } \\
\text { Ewes } \\
\text { Does }\end{array}$ & $\begin{array}{l}305 \\
1,103 \\
381 \\
36 \\
70 \\
40\end{array}$ & $\begin{array}{l}\text { Serum } \\
\text { Serum } \\
\text { Serum } \\
\text { Serum } \\
\text { Serum } \\
\text { Serum }\end{array}$ & $\begin{array}{l}7.86 \% \\
4.35 \% \\
7.61 \% \\
2.77 \% \\
5.71 \% \\
10 \%\end{array}$ & $\begin{array}{l}\text { Different localities in } \\
\text { lower Egypt }\end{array}$ & & Outbreak investigation \\
\hline$[36]$ & $\begin{array}{l}\text { BAPAT } \\
\text { RBT,TAT } \\
\text { ELISA } \\
\text { LAT }^{\S}, \text { ICA }^{\S}\end{array}$ & $\begin{array}{l}\text { Cattle } \\
\text { Sheep } \\
\text { Goats }\end{array}$ & $\begin{array}{l}376 \\
106 \\
158\end{array}$ & $\begin{array}{l}\text { Serum } \\
\text { Serum } \\
\text { Serum }\end{array}$ & $\begin{array}{l}5.32 \% \\
9.43 \% \\
8.86 \%\end{array}$ & Menufiya & & Outbreak investigation \\
\hline$[24]$ & $\begin{array}{l}\text { RBT } \\
\text { BAPAT } \\
\text { Riv.T } \\
\text { TAT } \\
\text { CFT }{ }^{\# \#} \\
\text { RBT } \\
\text { BAPAT } \\
\text { Riv.T } \\
\text { TAT } \\
\text { CFT }\end{array}$ & $\begin{array}{l}\text { Group } 1 \\
\text { cows } \\
\text { suspected }\end{array}$ & 180 & Serum & $\begin{array}{l}77.2 \% \\
79.4 \% \\
72.2 \% \\
81.1 \% \\
72.8 \% \\
1.6 \% \\
3.2 \% \\
0.8 \% \\
4 \% \\
0.8 \%\end{array}$ & & $\begin{array}{l}B . \\
\text { melitensis } \\
\text { bv } 3\end{array}$ & Outbreak investigation \\
\hline$[45]$ & $\begin{array}{l}\text { BAPAT } \\
\text { Brucella card } \\
\text { CFT }\end{array}$ & $\begin{array}{l}\text { Cattle } \\
\text { Buffalo- } \\
\text { cows } \\
\text { Sheep } \\
\text { Goats } \\
\text { Cattle } \\
\text { bulls } \\
\text { Buffalo } \\
\text { bulls }\end{array}$ & $\begin{array}{l}549 \\
338 \\
404 \\
336 \\
217 \\
152\end{array}$ & $\begin{array}{l}\text { Serum } \\
\text { Serum } \\
\text { Serum } \\
\text { Serum } \\
\text { Serum } \\
\text { Serum }\end{array}$ & $\begin{array}{l}14.57 \% \\
10 \% \\
25.4 \% \\
30.9 \% \\
6.9 \% \\
3.9 \%\end{array}$ & $\begin{array}{l}\text { Menufiya, Beni-Suef } \\
\text { Assuit, Giza, Gharbia, } \\
\text { Sharkia, Behira }\end{array}$ & $\begin{array}{l}B . \\
\text { melitensis } \\
\text { bv } 3\end{array}$ & Outbreak investigation \\
\hline$[30]$ & $\begin{array}{l}\text { RBT } \\
\text { SAT } \\
\text { ELISA } \\
\text { PCR }\end{array}$ & Sheep & 300 & Serum & $\begin{array}{l}29.3 \% \\
27 \% \\
28.3 \% \\
39 \%\end{array}$ & $\begin{array}{l}\text { Kafrelsheik, } \\
\text { Gharbiya }\end{array}$ & & Outbreak investigation \\
\hline$[31]$ & $\begin{array}{l}\text { Positive serum } \\
\text { samples }\end{array}$ & $\begin{array}{l}\text { Cattle } \\
\text { Sheep } \\
\text { Goats }\end{array}$ & $\begin{array}{l}32 \\
69 \\
5\end{array}$ & $\begin{array}{l}\text { L.N } \\
\text { Spleen }\end{array}$ & $\begin{array}{l}28.13 \% \\
36.23 \% \\
100 \%\end{array}$ & Assuit & $\begin{array}{l}B . \\
\text { melitensis } \\
\text { bv } 3\end{array}$ & No outbreak investigation \\
\hline$[38]$ & RBT & Swine & 230 & Serum & $12.61 \%$ & Cairo & B. suis & No outbreak investigation \\
\hline [29] & $\begin{array}{l}\text { BAPAT } \\
\text { RBPT } \\
\text { M.P.A.T } \\
\text { Riv.T, 2MT } \\
\text { ELISA }\end{array}$ & $\begin{array}{l}\text { Cattle } \\
\text { Buffaloes } \\
\text { Sheep } \\
\text { Goats }\end{array}$ & $\begin{array}{l}967 \\
462 \\
591 \\
539\end{array}$ & $\begin{array}{l}\text { Serum } \\
\text { Serum } \\
\text { Serum } \\
\text { Serum }\end{array}$ & $\begin{array}{l}6.72 \% \\
5.62 \% \\
7.61 \% \\
10.95 \%\end{array}$ & Sharkia & $\begin{array}{l}B \text {. } \\
\text { melitensis } \\
\text { bv } 3\end{array}$ & Outbreak Investigation \\
\hline$[35]$ & $\begin{array}{l}\text { BAPAT } \\
\text { RBT,SAT } \\
\text { Riv.T }\end{array}$ & $\begin{array}{l}\text { Cattle } \\
\text { Sheep } \\
\text { Goats }\end{array}$ & $\begin{array}{l}715 \\
1323 \\
100\end{array}$ & $\begin{array}{l}\text { Serum } \\
\text { Serum } \\
\text { Serum }\end{array}$ & $\begin{array}{l}4.5 \% \\
5.2 \% \\
5 \%\end{array}$ & Assiut & $\begin{array}{l}B . \\
\text { melitensis } \\
\text { bv } 3\end{array}$ & Outbreak investigation \\
\hline$[18]$ & $\begin{array}{l}\text { RBT } \\
\text { CFT }\end{array}$ & $\begin{array}{l}\text { Cattle } \\
\text { Buffalo } \\
\text { Sheep } \\
\text { Goats } \\
\text { Household }\end{array}$ & $\begin{array}{l}\text { Total } \\
120,077\end{array}$ & $\begin{array}{l}\text { Serum } \\
\text { data } \\
\text { from } \\
\text { GOVS }\end{array}$ & $\begin{array}{l}0.79 \% \\
0.13 \% \\
1.16 \% \\
0.44 \% \\
1.2 \%\end{array}$ & $\begin{array}{l}\text { Beni-Suef, El-Minia, } \\
\text { Assiut, Sohag, Qina, } \\
\text { Luxor, Aswan }\end{array}$ & & Official data \\
\hline
\end{tabular}




\begin{tabular}{|c|c|c|c|c|c|c|c|c|}
\hline Reference & $\begin{array}{l}\text { Serology } \\
\text { tests }\end{array}$ & $\begin{array}{l}\text { Animals } \\
\text { tested }\end{array}$ & $\begin{array}{l}\text { Sample } \\
\text { no. }\end{array}$ & $\begin{array}{l}\text { Sample } \\
\text { type }\end{array}$ & Prevalence & Location & Isolates & Inclusion criteria \\
\hline [19] & $\begin{array}{l}\text { RBT, CFT } \\
\text { iELISA }\end{array}$ & $\begin{array}{l}\text { Cattle } \\
\text { Buffaloes } \\
\text { Sheep } \\
\text { Goats }\end{array}$ & $\begin{array}{l}188 \\
173 \\
791 \\
383\end{array}$ & $\begin{array}{l}\text { Milk } \\
\text { Milk } \\
\text { Serum } \\
\text { Serum }\end{array}$ & $\begin{array}{l}15.1 \% \\
15.1 \% \\
41.3 \% \\
32.2 \%\end{array}$ & Kafrelsheikh & & $\begin{array}{l}\text { A cross-sectional study was } \\
\text { carried out among dairy cattle, } \\
\text { buffalos, sheep and goats and a } \\
\text { multistage random sampling } \\
\text { strategy was used to select } \\
\text { cattle milk tanks and individual } \\
\text { sheep and goats within the } \\
\text { governorate. The first-level } \\
\text { sampling unit in this study was } \\
\text { the village, the second-level } \\
\text { sampling units were the cattle } \\
\text { milk tanks and the individual } \\
\text { sheep/goat. }\end{array}$ \\
\hline [6] & iELISA & $\begin{array}{l}\text { Cattle } \\
\text { Buffaloes } \\
\text { Household }\end{array}$ & $\begin{array}{l}109 \\
46 \\
104\end{array}$ & $\begin{array}{l}\text { Milk } \\
\text { Milk }\end{array}$ & $\begin{array}{l}\text { Total } \mathrm{n}= \\
2214.6 \% \\
15.5 \%\end{array}$ & Menufiya & & $\begin{array}{l}\text { A cross-sectional study was } \\
\text { carried out in a village. The } \\
\text { village was selected due to } \\
\text { convenience. The study } \\
\text { population comprised all } \\
\text { households with lactating } \\
\text { cattle and buffalo in the } \\
\text { village. There was no sampling } \\
\text { frame in the village and all } \\
\text { lactating cattle and buffaloes } \\
\text { were sampled. }\end{array}$ \\
\hline [34] & $\begin{array}{l}\text { RBT, Riv T } \\
\text { PCR }\end{array}$ & $\begin{array}{l}\text { Nile } \\
\text { catfish }\end{array}$ & $\begin{array}{l}120 \\
\text { from } \\
\text { Nile } \\
120 \\
\text { from } \\
\text { Farm }\end{array}$ & $\begin{array}{l}\text { Serum } \\
\text { Skin } \\
\text { Liver } \\
\text { Kidney } \\
\text { Spleen }\end{array}$ & $\begin{array}{l}8.3 \% \\
\text { Only from } \\
\text { Nile }\end{array}$ & $\begin{array}{l}\text { KafrelsheikhMenufiya, } \\
\text { Gharbiya, Dakahlia, } \\
\text { Behira }\end{array}$ & $\begin{array}{l}\text { B. } \\
\text { melitensis } \\
\text { bv } 3\end{array}$ & $\begin{array}{l}\text { Samples collected from } 17 \\
\text { sites in small tributaries of Nile } \\
\text { canals. } 120 \text { catfish were } \\
\text { collected from } 7 \text { fish farms } \\
\text { from Kafrelsheikh, Behira and } \\
\text { Dakahlia governorates unlikely } \\
\text { to be exposed to water } \\
\text { contaminated by carcasses and } \\
\text { other contaminated animal } \\
\text { materials. }\end{array}$ \\
\hline [64] & $\begin{array}{l}\text { RBT } \\
\text { SAT } \\
\text { iELISA }\end{array}$ & Buffaloes & 452 & Serum & $\begin{array}{l}12.83 \% \\
11.28 \% \\
19.25 \%\end{array}$ & & $\begin{array}{l}B \\
\text { melitensis } \\
\text { bv } 3\end{array}$ & Outbreak investigation \\
\hline [27] & RBT, iELISA & $\begin{array}{l}\text { Sheep } \\
\text { Goats } \\
\text { Cattle } \\
\text { Sheep } \\
\text { herd } \\
\text { Goats } \\
\text { herd } \\
\text { Cattle } \\
\text { herd }\end{array}$ & $\begin{array}{l}\text { Total } \\
1670 \\
\\
45 \\
55 \\
26\end{array}$ & $\begin{array}{l}\text { Serum } \\
\text { Serum } \\
\text { Serum } \\
\text { Serum } \\
\text { Serum } \\
\text { Serum }\end{array}$ & $\begin{array}{l}21.20 \% \\
14.2 \% \\
2.16 \% \\
26.66 \% \\
18.88 \% \\
21.6 \%\end{array}$ & & & $\begin{array}{l}\text { A cross-sectional study was } \\
\text { carried out on different } \\
\text { governorates. } \\
\text { In each region, blood samples } \\
\text { were taken from herds/flocks } \\
\text { with no previous history of } \\
\text { vaccination against Brucella. } \\
\text { The number of samples was } \\
\text { collected in simple and/or } \\
\text { systemic random sampling as } \\
\text { follows: animals from each } \\
\text { herd were randomly selected } \\
\text { using a table of random digits. } \\
\text { Only female cows older than } 6 \\
\text { months of age were sampled. } \\
\text { The herds were stratified into } \\
\text { three herd sizes: small herds }(\leq \\
50) \text {, medium herds }(50-150) \\
\text { and large herds }(>150) \text {. }\end{array}$ \\
\hline [28] & CFT & Camels & 340 & Serum & $7.35 \%$ & Behira & $\begin{array}{l}\text { B. } \\
\text { melitensis } \\
\text { B. abortus }\end{array}$ & No outbreak investigation \\
\hline [48] & $\begin{array}{l}\text { BAPAT } \\
\text { RBT, Riv T }\end{array}$ & $\begin{array}{l}\text { Cattle } \\
\text { Buffaloes }\end{array}$ & $\begin{array}{l}7,102 \\
2,895\end{array}$ & Serum & $\begin{array}{l}0.20- \\
0.37 \% \\
0.11- \\
0.38 \%\end{array}$ & Kafrelsheikh & $\begin{array}{l}\text { B. } \\
\text { melitensis } \\
\text { bv } 3\end{array}$ & Outbreak investigation \\
\hline [23] & $\begin{array}{l}\text { SAT } \\
\text { BAPAT } \\
\text { RBT } \\
\text { Riv T } \\
\text { SAT } \\
\text { BAPAT }\end{array}$ & 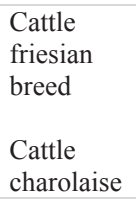 & 43 & Serum & $\begin{array}{l}8.77 \% \\
10.53 \% \\
10.53 \% \\
8.77 \% \\
6.68 \% \\
9.30 \%\end{array}$ & Egypt & & Breed \\
\hline
\end{tabular}




\begin{tabular}{|c|c|c|c|c|c|c|c|c|}
\hline Reference & $\begin{array}{l}\text { Serology } \\
\text { tests }\end{array}$ & $\begin{array}{l}\text { Animals } \\
\text { tested }\end{array}$ & $\begin{array}{l}\text { Sample } \\
\text { no. }\end{array}$ & $\begin{array}{l}\text { Sample } \\
\text { type }\end{array}$ & Prevalence & Location & Isolates & Inclusion criteria \\
\hline & $\begin{array}{l}\text { RBT } \\
\text { Riv T }\end{array}$ & breed & & & $\begin{array}{l}11.63 \% \\
4.65 \%\end{array}$ & & & \\
\hline$[22]$ & $\begin{array}{l}\text { BAPAT } \\
\text { RBT, SAT } \\
\text { Riv T }\end{array}$ & $\begin{array}{l}\text { Cattle } \\
\text { Buffaloes } \\
\text { Sheep } \\
\text { Goats }\end{array}$ & $\begin{array}{l}1,966 \\
1,237 \\
813 \\
366\end{array}$ & $\begin{array}{l}\text { Milk } \\
\text { Tissue }\end{array}$ & $\begin{array}{l}5.44 \% \\
4.11 \% \\
5.41 \% \\
3.55 \%\end{array}$ & $\begin{array}{l}\text { Beni-Suef, Assiut, } \\
\text { Alexandria, Giza, } \\
\text { Behira Qaliobia, } \\
\text { Menufiya. }\end{array}$ & $\begin{array}{l}B \text {. } \\
\text { melitensis } \\
\text { bv } 3\end{array}$ & No brucellosis history \\
\hline$[17]$ & $\begin{array}{l}\text { BAPAT } \\
\text { RBPT, TAT } \\
\text { Riv T, CFT } \\
\text { PCR }\end{array}$ & $\begin{array}{l}\text { Baladi } \\
\text { does }\end{array}$ & 577 & Serum & $\begin{array}{l}3.11 \% \\
\text { to } \\
5.71 \%\end{array}$ & Kafrelsheikh & $\begin{array}{l}B \text {. } \\
\text { melitensis } \\
\text { bv } 3\end{array}$ & Outbreak investigation \\
\hline$[32]$ & $\begin{array}{l}\text { BAPAT } \\
\text { RBT, TAT } \\
\text { Riv T }\end{array}$ & $\begin{array}{l}\text { Livestock } \\
\text { Cattle } \\
\text { Buffaloes } \\
\text { Sheep } \\
\text { Goats }\end{array}$ & $\begin{array}{l}350 \\
77 \\
35 \\
29 \\
18\end{array}$ & $\begin{array}{l}\text { Serum } \\
\text { Serum } \\
\text { Serum } \\
\text { Serum } \\
\text { Serum }\end{array}$ & & Gharbiya & & $\begin{array}{l}\text { A cross-sectional survey was } \\
\text { conducted in two villages. } \\
\text { Criteria for inclusions of the } \\
\text { villages were easy accessibility } \\
\text { for the study team and a } \\
\text { population size of } \\
\text { approximately } 5,000 \text { in each } \\
\text { village. Each village was } \\
\text { divided into small clusters } \\
\text { from which one house was } \\
\text { randomly selected. Members } \\
\text { (aged } \geq 3 \text { years) and their } \\
\text { livestock were enrolled until } \\
\text { the sample size was achieved. }\end{array}$ \\
\hline$[63]$ & $\begin{array}{l}\text { MRT, wTAT } \\
\text { wRBPT } \\
\text { wBAPAT } \\
\text { wRiv T }\end{array}$ & $\begin{array}{l}\text { Cattle } \\
\text { Buffaloes }\end{array}$ & $\begin{array}{l}210 \\
50\end{array}$ & $\begin{array}{l}\text { Raw } \\
\text { milk } \\
\text { Raw } \\
\text { milk }\end{array}$ & $\begin{array}{l}12.38 \% \\
0.00 \%\end{array}$ & Assiut & & No outbreak investigation \\
\hline$[33]$ & $\begin{array}{l}\text { SAT, RBT } \\
\text { Riv T, } \\
\text { CFT } \\
\text { PCR }\end{array}$ & $\begin{array}{l}\text { Ewes } \\
\text { native } \\
\text { breed }\end{array}$ & 32 & Serum & $\begin{array}{l}31.25 \% \\
25.00 \% \\
21.88 \% \\
21.88 \%\end{array}$ & Menufiya & $\begin{array}{l}B . \\
\text { melitensis } \\
\text { bv } 3 \\
B . \\
\text { melitensis } \\
\text { Rev } 1\end{array}$ & No outbreak investigation \\
\hline$[61]$ & $\begin{array}{l}\text { RBPT, BAPAT } \\
\text { TAT, Riv T } \\
\text { ELISA }\end{array}$ & $\begin{array}{l}\text { Cattle } \\
\text { Sheep } \\
\text { Buffaloes } \\
\text { Dairy } \\
\text { cows }\end{array}$ & $\begin{array}{l}197 \\
129 \\
32 \\
41\end{array}$ & $\begin{array}{l}\text { Serum } \\
\text { Serum } \\
\text { Serum } \\
\text { Milk }\end{array}$ & $\begin{array}{l}3.6 \% \\
11.6 \% \\
0.00 \% \\
7.3 \%\end{array}$ & Assiut & & No outbreak investigation \\
\hline$[71]$ & $\begin{array}{l}\text { BAPAT, RBT } \\
\text { SAT, Riv T } \\
\text { ELISA }\end{array}$ & $\begin{array}{l}\text { Cattle } \\
\text { Sheep } \\
\text { Goats } \\
\text { Camels } \\
\text { Cattle } \\
\text { Sheep } \\
\text { Goats } \\
\text { Camels }\end{array}$ & $\begin{array}{l}180 \\
180 \\
100 \\
100 \\
15 \\
16 \\
36 \\
10\end{array}$ & $\begin{array}{l}\text { Serum } \\
\text { Serum } \\
\text { Serum } \\
\text { Serum } \\
\text { Milk } \\
\text { Milk } \\
\text { Milk } \\
\text { Milk }\end{array}$ & $\begin{array}{l}7.22- \\
10.56 \% \\
2.22-3.89 \% \\
6-7 \% \\
0.00 \% \\
6.67 \% \\
6.25 \% \\
2.78 \% \\
0.00 \%\end{array}$ & New Valley & & 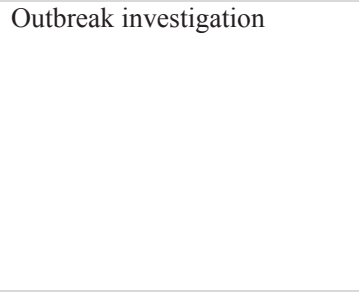 \\
\hline$[57]$ & $\begin{array}{l}\text { RBPT, BAPT } \\
\text { TAT, Riv T }\end{array}$ & $\begin{array}{l}\text { Ewes } \\
\text { Rams } \\
\text { Does } \\
\text { Bucks } \\
\text { Ewes } \\
\text { Rams } \\
\text { Does } \\
\text { Bucks }\end{array}$ & $\begin{array}{l}450 \\
300 \\
220 \\
180 \\
426 \\
210 \\
105 \\
70\end{array}$ & $\begin{array}{l}\text { Serum } \\
\text { Serum } \\
\text { Serum } \\
\text { Serum } \\
\text { Serum } \\
\text { Serum } \\
\text { Serum } \\
\text { Serum }\end{array}$ & $\begin{array}{l}\text { Total } \\
1.26 \% \\
\\
\text { Total } \\
9.30 \%\end{array}$ & $\begin{array}{l}\text { Assiut } \\
\text { Sohag }\end{array}$ & & No outbreak investigation \\
\hline$[65]$ & $\begin{array}{l}\text { RBPT } \\
\text { STAT } \\
\text { ELISA } \\
\text { RBPT } \\
\text { STAT } \\
\text { ELISA }\end{array}$ & $\begin{array}{l}\text { Local } \\
\text { camels } \\
\text { Imported } \\
\text { camels }\end{array}$ & 31 & Serum & $\begin{array}{l}9.47 \% \\
5.26 \% \\
9.47 \% \\
6.67 \% \\
9.67 \% \\
25.80 \%\end{array}$ & $\begin{array}{l}\text { Halaieb, Shalateen, } \\
\text { Abo-Ramad triangle }\end{array}$ & & No outbreak investigation \\
\hline$[46]$ & $\begin{array}{l}\text { RBPT, TAT } \\
\text { BAPT, Riv T }\end{array}$ & Camels & 300 & Serum & $\begin{array}{l}3.04 \% \\
0.00 \%\end{array}$ & $\begin{array}{l}\text { Assuit } \\
\text { New Valley }\end{array}$ & & No outbreak investigation \\
\hline$[60]$ & $\begin{array}{l}\text { RBPT, SAT, } \\
\text { MET }^{\S \S}, \text { Riv T } \\
\text { DIA }\end{array}$ & $\begin{array}{l}\text { Camels in } \\
\text { closed } \\
\text { farm } \\
\text { Imported }\end{array}$ & $\begin{array}{l}80 \\
94\end{array}$ & $\begin{array}{l}\text { Serum } \\
\text { Serum }\end{array}$ & $\begin{array}{l}0.0-2.5 \% \\
8.5-11.70 \%\end{array}$ & Giza & & No outbreak investigation \\
\hline
\end{tabular}




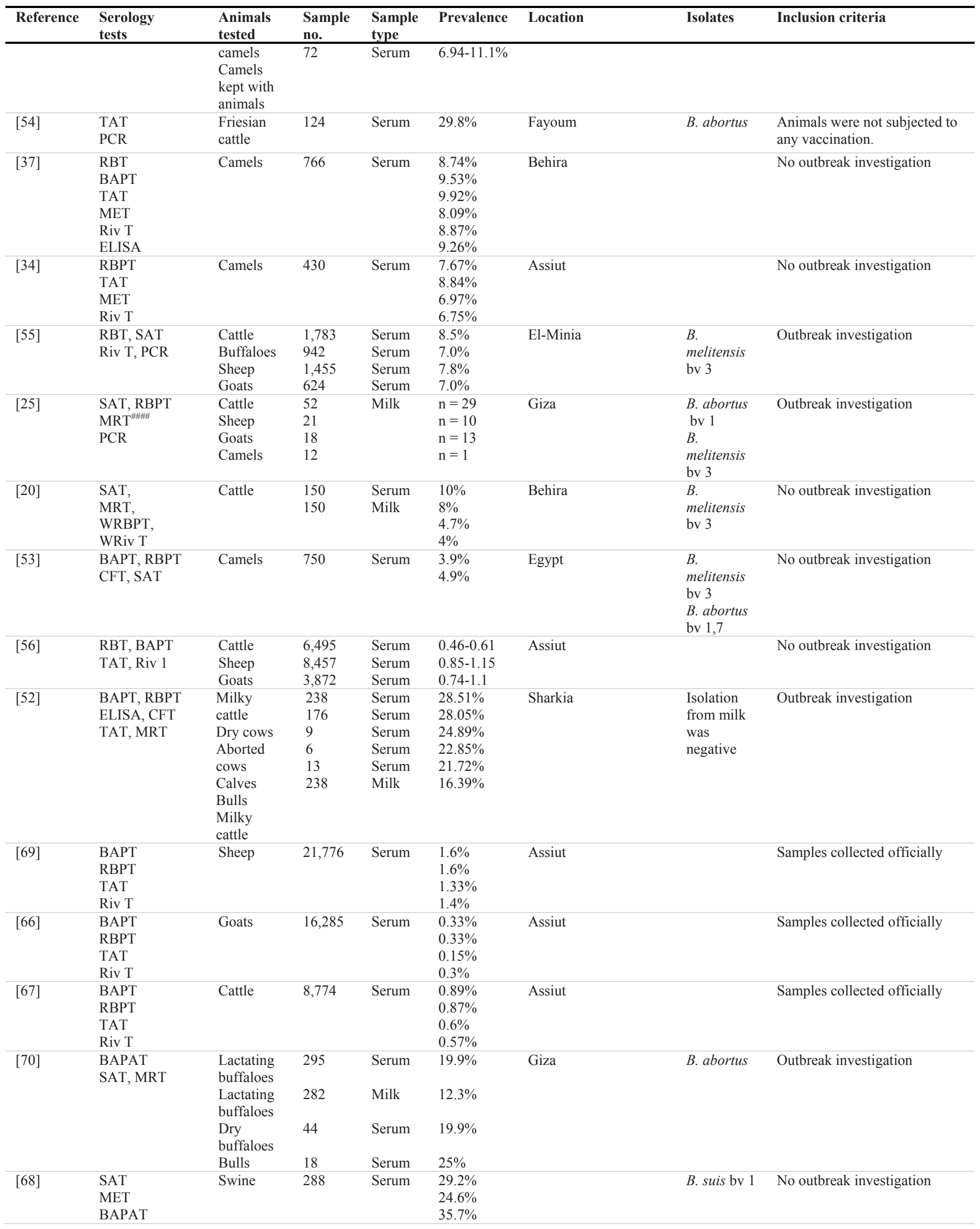




\begin{tabular}{|c|c|c|c|c|c|c|c|c|}
\hline Reference & $\begin{array}{l}\text { Serology } \\
\text { tests }\end{array}$ & $\begin{array}{l}\text { Animals } \\
\text { tested }\end{array}$ & $\begin{array}{l}\text { Sample } \\
\text { no. }\end{array}$ & $\begin{array}{l}\text { Sample } \\
\text { type }\end{array}$ & Prevalence & Location & Isolates & Inclusion criteria \\
\hline & RBT & & & & $29 \%$ & & & \\
\hline & Riv T & & & & $27.4 \%$ & & & \\
\hline \multirow[t]{4}{*}{ [49] } & SAT, MET & Cattle & 1,683 & Serum & $8.2 \%$ & \multirow{4}{*}{$\begin{array}{l}\text { Alexandria, Assiut, } \\
\text { Cairo, Giza, Behira, } \\
\text { Demiatta, Fayoum, } \\
\text { Gharbiya, } \\
\text { Kafrelsheik, Qaliobia, } \\
\text { Menufiya, Suez, Port- } \\
\text { Said, Sharkia }\end{array}$} & $B$. & \multirow[t]{4}{*}{ Outbreak investigation } \\
\hline & BAPAT & Buffaloes & 1,286 & Serum & $11.4 \%$ & & melitensis & \\
\hline & RBPT, Riv T & Sheep & 2,257 & Serum & $5.1 \%$ & & bv 3 & \\
\hline & & Goats & 532 & Serum & $11.1 \%$ & & $\begin{array}{l}\text { B. abortus } \\
\text { bv } 1\end{array}$ & \\
\hline \multirow[t]{4}{*}{ [59] } & RBPT & Cattle & 176 & Serum & $2.27 \%$ & \multirow[t]{4}{*}{ Kafrelsheikh } & & \multirow[t]{4}{*}{ No outbreak investigation } \\
\hline & & Buffaloes & 97 & Serum & $3.09 \%$ & & & \\
\hline & & Sheep & 169 & Serum & $4.73 \%$ & & & \\
\hline & & Goats & 20 & Serum & $0.00 \%$ & & & \\
\hline \multirow[t]{4}{*}[58]{} & TAT & Camels & 1,500 & Serum & $5.3 \%$ & \multirow[t]{4}{*}{ Egypt } & \multirow{4}{*}{$\begin{array}{l}\text { B. abortus } \\
\text { bv } 7\end{array}$} & \multirow[t]{4}{*}{ No outbreak investigation } \\
\hline & MT & & & & $6.33 \%$ & & & \\
\hline & TAT & & & & $6.4 \%$ & & & \\
\hline & CFT & & & & $7.93 \%$ & & & \\
\hline \multirow[t]{4}{*}[47]{} & STA, RBPT & Friesian & 533 & Serum & $4.48 \%$ & \multirow[t]{4}{*}{ Menufiya } & \multirow{4}{*}{$\begin{array}{l}\text { No } \\
\text { isolation }\end{array}$} & \multirow[t]{4}{*}{ Outbreak investigation } \\
\hline & 2ME, MRT & cattle & & & & & & \\
\hline & CFT, Riv T & Native & 302 & Serum & $6.43 \%$ & & & \\
\hline & & cattle & 547 & Serum & $2.89 \%$ & & & \\
\hline \multirow{4}{*}[50]{} & TAT, Riv T & $\begin{array}{l}\text { Burraloes } \\
\text { Sheep }\end{array}$ & 925 & Serum & $13.3 \%$ & \multirow{4}{*}{$\begin{array}{l}\text { Cairo, Giza, Qaliobia, } \\
\text { Kafrelsheik,Dakahlia }\end{array}$} & & \multirow{4}{*}{ Outbreak investigation } \\
\hline & BAPAT & Goats & 560 & Serum & $7.14 \%$ & & $\begin{array}{l}\text { D. } \\
\text { melitensis }\end{array}$ & \\
\hline & RBPT, MET & Sheep & 25 & Milk & $40 \%$ & & bv 3 & \\
\hline & MRT & Goats & 21 & Milk & $23.8 \%$ & & & \\
\hline \multirow[t]{6}{*}[21]{} & TAT & Cattle & 1,832 & Serum & $37.9 \%$ & & $B$. & \multirow[t]{6}{*}{ No outbreak investigation } \\
\hline & Riv T & & & & $32.8 \%$ & & melitensis & \\
\hline & RBT & & & & $61.8 \%$ & & bv 3 & \\
\hline & TAT & Buffaloes & 118 & Serum & $10.2 \%$ & & B.abortus & \\
\hline & Riv T & & & & $7.8 \%$ & & bv 3,7 & \\
\hline & $\mathrm{RBT}$ & & & & $22.2 \%$ & & & \\
\hline \multirow[t]{6}{*}[44]{} & CFT, TAT & Cattle & 800 & Serum & $3 \%$ & \multirow{6}{*}{$\begin{array}{l}\text { Menufiya, Beni-Suef, } \\
\text { Kafrelsheikh, Fayoum }\end{array}$} & $B$ & \multirow[t]{6}{*}{ Outbreak investigation } \\
\hline & BAPAT, RBPT & Buffaloes & 300 & Serum & $4 \%$ & & melitensis & \\
\hline & Riv T, MRT & Cattle & 800 & Milk & $2.63 \%$ & & bv 3 & \\
\hline & & Buffaloes & 300 & Milk & $3.67 \%$ & & B. abortus & \\
\hline & & Dogs & 108 & Serum & $6.48 \%$ & & bv 3,7 & \\
\hline & & Wild rats & 130 & Serum & $10.77 \%$ & & & \\
\hline \multirow[t]{4}{*}{ [51] } & TAT, Riv T & Cattle & 1,832 & Serum & $37.99 \%$ & Alexandria, Assiut, & $B$ & \multirow[t]{4}{*}{ Outbreak investigation } \\
\hline & RBPT, MRT & Buffaloes & 118 & Serum & $10.17 \%$ & Cairo, Giza, Demiatta, & melitensis & \\
\hline & & Sheep & 648 & Serum & $23.92 \%$ & Kafrelsheik,Qaliobia, & bv 3 & \\
\hline & & Goats & 131 & Serum & $00.00 \%$ & $\begin{array}{l}\text { Menufiya, Port-Said, } \\
\text { El-Menia, Beni-suef, } \\
\text { Dakahlia }\end{array}$ & $\begin{array}{l}\text { B. abortus } \\
\text { bv } 3,7\end{array}$ & \\
\hline
\end{tabular}

${ }^{*}$ Buffer acidified plate antigen test (BAPAT)

${ }^{* *}$ Rose Bengal test (RBT)

${ }^{* * *}$ Tube agglutination test (SAT)

${ }^{* * * *}$ Rivanol test (Riv. T)

${ }^{* * * * *}$ Milk ring test (MRT)

${ }^{* * * * * *}$ Polymerase chain reaction $(\mathrm{PCR})$

"Enzyme linked immunosorbent assay (ELISA)

\#\# Dot blot hybridization assay (DBH)

\#\#\# Complement fixation test

\#\#\# Milk ring test

${ }^{\S}$ Latex agglutination test (LAT)

${ }^{\S}$ Immunochromatographic assay (ICA)

$\S \S \S$ Mercapteoethanol test (MET) 